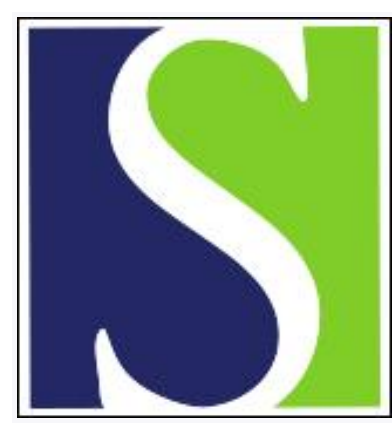

Scand J Work Environ Health 1989;15(2):142-146

https://doi.org/10.5271/sjweh.1870

Issue date: Apr 1989

Cell response in bronchoalveolar lavage fluid after sulfur dioxide exposure.

by Sandstrom T, Stjernberg N, Andersson MC, Kolmodin-Hedman B, Lindstrom K, Rosenhall L

Affiliation: Department of Lung Medicine, University Hospital, Umea, Sweden.

This article in PubMed: www.ncbi.nlm.nih.gov/pubmed/2772577

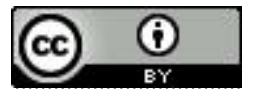




\title{
Cell response in bronchoalveolar lavage fluid after sulfur dioxide exposure
}

\author{
by Thomas Sandström, MD, ${ }^{1}$ Nils Stjernberg, MD, PhD, ${ }^{2}$ Maj-Cari Andersson, BA, ${ }^{2}$ \\ Birgitta Kolmodin-Hedman, MD, $\mathrm{PhD},{ }^{2}$ Karin Lindström, BSc, ${ }^{2}$ Leif Rosenhall, MD, $\mathrm{PhD}^{1}$
}

\begin{abstract}
SANDSTRÖM T, STJERNBERG N, ANDERSSON M-C, KOLMODIN-HEDMAN B, LINDSTRÖM $\mathrm{K}$, ROSENHALL L. Cell response in bronchoalveolar lavage fluid after sulfur dioxide exposure. Scand $J$ Work Environ Health 1989;15:142-6. Environmental chamber exposure and bronchoalveolar lavage (BAL) were used to study the dose-response relationship between short-term exposure to sulfur dioxide $\left(\mathrm{SO}_{2}\right)$ and inflammatory reactions in the human lung as reflected in BAL fluid. Healthy subjects were exposed to $10,13,20$, or $30 \mathrm{mg} / \mathrm{m}^{3}$ for $20 \mathrm{~min}$. BAL was performed several weeks preexposure and $24 \mathrm{~h}$ postexposure. Mast cells, lymphocytes, lysozyme positive macrophages, and the total number of macrophages were significantly increased after $\mathrm{SO}_{2}$ exposure. A dose-dependent increase in the cell response in BAL fluid was observed after exposure to $10-20 \mathrm{mg} / \mathrm{m}^{3}$, but no further increase was detected after $30 \mathrm{mg} / \mathrm{m}^{3}$. Inflammatory cell response was found in $\mathrm{BAL}$ fluid at $\mathrm{SO}_{2}$ levels that occur in industrial indoor environments worldwide, and cell response to $\mathrm{SO}_{2}$ was also seen below the short-term exposure limit of Sweden and many other countries $\left(13 \mathrm{mg} / \mathrm{m}^{3}\right)$.
\end{abstract}

Key terms: lymphocytes, lysozyme, macrophages, mast cells.

Long-term exposure to sulfur dioxide $\left(\mathrm{SO}_{2}\right)$ is known to increase the morbidity of chronic bronchitis and obstructive airway diseases $(1-5)$. The increased morbidity may occur after long-term exposure both to polluted outdoor ambient air of industrialized areas and to indoor air in certain kinds of industries. The highest $\mathrm{SO}_{2}$ concentrations are found in indoor environments in, eg, paper pulp industries, smelteries, and petroleum refineries. The morbidity of lung diseases among workers in these industries is often markedly increased even when compared with that of residents in the surrounding areas $(4,6,7)$.

Even though several studies on the lung effects of $\mathrm{SO}_{2}$ have appeared in the literature $(8-12)$, the basal and primary mechanisms that cause the noxious effects have not been clarified. In a recent study we have demonstrated the usefulness of combining controlled chamber exposure and bronchoalveolar lavage (BAL) in the investigation of these mechanisms (13). We have recently studied the time course of the inflammatory reaction in human lung after $\mathrm{SO}_{2}$ exposure and have found that inflammatory cell response in BAL fluid occurs after moderately high concentrations of $\mathrm{SO}_{2}$ with peak effects $24 \mathrm{~h}$ after exposure (to be published). These results have raised questions about the safety of the short-term exposure limits set for $\mathrm{SO}_{2}$ in industrialized countries.

1 Department of Lung Medicine, University Hospital, Umeå, Sweden.

- National Institute of Occupational Health, Medical Division, Umeå, Sweden.

Reprint requests to: Dr T Sandström, Department of Lung Medicine, University Hospital, S-901 85 Umeå, Sweden.
Using these observations as a starting point, we have performed the present study to determine the exposure dose-response relationship between short-term exposure to $\mathrm{SO}_{2}$ and the inflammatory response in human lung.

\section{Subjects and methods}

\section{Subjects}

Twenty-two healthy nonsmoking male volunteers between the ages of 22 and 37 years (mean 27 years) gave their informed consent to participate in this investigation. None of them had a history of bronchial hyperreactivity or a history of airway infection during at least six weeks prior to the BAL. The preexposure dynamic spirometry values were normal for all the subjects.

\section{Design of the study}

The subjects were exposed to $\mathrm{SO}_{2}$ concentrations of $10,13,20$, or $30 \mathrm{mg} / \mathrm{m}^{3}(4,5,8$, or $11 \mathrm{ppm}$, respectively) for $20 \mathrm{~min}$. Ten subjects were exposed to 10 $\mathrm{mg} / \mathrm{m}^{\prime}$ and eight subjects to each of the other concentrations. Flexible fiberoptic bronchoscopy with BAL was performed on all of the subjects at least two weeks before $\mathrm{SO}_{2}$ exposure in order to obtain reference values for the BAL fluid. BAL was then performed $24 \mathrm{~h}$ after the end of the exposures. All the lavages were performed within $20 \mathrm{~min}$ of the scheduled time. Each volunteer was exposed one to three times. The period between the $\mathrm{SO}_{2}$ exposures was at least three weeks. Immediately before and after the exposures the subjects' lung function values were recorded with a 
Vitálograph ${ }^{(8)}$ spirometer. Spirometry was also performed before the postexposure BAL. Before, during, and at the end of the exposure, the subjects were asked about symptoms from their eyes, nose, and airways according to a standardized questionnaire (14).

\section{Sulfur dioxide exposure}

The chamber exposure was designed to simulate the work conditions that have previously been identified in, eg, pulp mills and smelteries with respect to the exposure concentration, work load, breathing pattern, and exposure time $(4,5)$. The exposure method has previously been described in detail (14). The exposure chamber measured $3.20 \times 2.00 \times 2.20 \mathrm{~m}$ with an air volume of $14.1 \mathrm{~m}^{3}$. It was constructed of anodized aluminum with windows in one wall. Ambient air was drawn continuously through the chamber at $150 \mathrm{~m}^{3} / \mathrm{h}$, the result being one air exchange approximately every $5 \mathrm{~min}$. Preexposure measurements showed very low levels of particulate matter in the chamber. During the exposures, the chamber air temperature was kept at $20^{\circ} \mathrm{C}$, and the relative humidity at around $50 \%$. The $\mathrm{SO}_{2}$ concentration in the exposure chamber was controlled by the addition of a gas stream from a $1 \%$ $\mathrm{SO}_{2}$ gas tube attached to the chamber air inlet. The chamber air was continuously analyzed with an electrochemical method, with which $\mathrm{SO}_{2}$ is oxidized to sulfate and the current is registered on a recorder. The method has previously been described in detail (15). The subjects were exposed to $\mathrm{SO}_{2}$ in the chamber for $20 \mathrm{~min}$. During the last $15 \mathrm{~min}$ of the exposure the subjects worked on a bicycle ergometer with a work load of $75 \mathrm{~W}$ and were therefore mainly breathing through the nose.

\section{Bronchoalveolar lavage}

The subjects were given atropine subcutaneously before the examination. No complementary medication was given other than lidocaine, which was administered according to a standardized scheme for topical anesthesia. A flexible fiberoptic bronchoscope (Olympus BF $1 \mathrm{~T}$ or $\mathrm{BF} 1 \mathrm{~T} 10$ ) was inserted through the mouth with the patient in the supine position. After careful wedging of the bronchoscope tip in the middle lobe bronchus, sterile phosphate buffered saline $\mathrm{pH} 7.3$ (PBS-A) at $37^{\circ} \mathrm{C}$ was infused in four aliquots of $60 \mathrm{ml}$ and gently suctioned back after each infusion to a siliconized container placed in ice water. Informed consent was obtained from the subjects, and the study was approved by the Ethics Committee of the University of Umeå. The investigator who performed all the bronchoscopies had knowledge of the exposure concentrations to which the subjects had been exposed before the bronchoscopy.

The chilled recovered BAL fluid was immediately filtered through a nylon filter (pore diameter $100 \mu \mathrm{m}$, Syntab Product AB, Malmö, Sweden) at the laboratory and centrifuged at $400 \mathrm{~g}$ for $15 \mathrm{~min}$. The cell pellet was resuspended in balanced salt solution to a concentration of $10^{6}$ cells per milliliter. The total number of cells in the lavage fluid was counted in a Bürker chamber.

Cytocentrifugal smears were prepared with $5 \times 10^{4}$ nonepithelial cells per slide with the use of a Cytospin $2^{(\text {p) }}$ (Shandon Southern Instruments Inc, Sewickly, Pennsylvania, United States). The slides were stained according to May-Grünwald-Giemsa for standard cell differential counts, and 200 cells per slide were counted. Mast cells were counted on slides stained with acid toluidine blue and counterstained with Mayer's acid hematoxyllin (16). Lysozyme positive macrophages were demonstrated with Lysozyme ${ }^{(x)}$ antibody with the use of an immunoperoxidase technique (Dakopatts A/S, Copenhagen, Denmark). The ratio $\mathrm{T}$ helper/cytotoxic-suppressor cells was determined with the Simultest T Helper/Supressor Test ${ }^{\text {ip) }}$ (Becton Dickinsson AB, Stockholm, Sweden). Albumin was measured by electroimmunoassay (17).

\section{Statistics}

Wilcoxon's nonparametric signed rank test for paired observations was used for comparing the BAL parameters of the same individual before and after exposure. A P-value of $<0.05$ was considered significant.

\section{Results}

\section{Bronchoscopy}

All the subjects had normal endobronchial findings in the reference bronchoscopy before exposure and after exposure to $\mathrm{SO}_{2}$ concentrations of 10 and 13 $\mathrm{mg} / \mathrm{m}^{3}$ ( 4 and $5 \mathrm{ppm}$, respectively). Twenty-four hours after exposure to $20 \mathrm{mg} / \mathrm{m}^{3}$ ( $8 \mathrm{ppm}$ ) mucosal erythema was found in the distal half of the trachea and proximal main bronchi of all the subjects. The erythema was even more pronounced $24 \mathrm{~h}$ after exposure to $30 \mathrm{mg} / \mathrm{m}^{3}(11 \mathrm{ppm})$.

The median amount of BAL fluid recovered after the reference BAL, before exposure, was $75 \%$ of the instilled volume (interquartile range $66-75 \%$ ). The recovery did not significantly differ after exposure to different concentrations. The counts for lymphocytes, alveolar macrophages/monocytes, and mast cells are given in table 1. A significant increase in the total number of cells was found in the BAL fluid $24 \mathrm{~h}$ after exposure to 20 and $30 \mathrm{mg} / \mathrm{m}^{3}$ ( 8 and $11 \mathrm{ppm}$, respectively). The increase consisted of lymphocytes, alveolar macrophages/monocytes, and mast cells, while the eosinophil and neutrophil levels were unaffected. Epithelial cells were few.

Lysozyme positive macrophages/monocytes were significantly increased at all the examined concentrations. The total number of alveolar macrophages/ monocytes was significantly increased $24 \mathrm{~h}$ after exposure to 20 and $30 \mathrm{mg} / \mathrm{m}^{3}$ ( 8 and $11 \mathrm{ppm}$, respective- 
Table 1. Cell numbers and the albumin concentration in bronchoalveolar lavage fluid before and $24 \mathrm{~h}$ after chamber exposure to sulfur dioxide concentrations of $10,13,20$, and $30 \mathrm{mg} / \mathrm{m}^{3}$.

\begin{tabular}{|c|c|c|c|c|c|c|c|c|c|c|}
\hline \multirow{2}{*}{ Time of measurement } & \multirow{2}{*}{$\begin{array}{l}\text { Total } \\
\text { number } \\
\text { of cells } \\
\left(\times 10^{7} / 1\right)\end{array}$} & \multicolumn{2}{|c|}{ Lymphocytes } & \multicolumn{2}{|c|}{$\begin{array}{l}\text { Macrophages/ } \\
\text { monocytes }\end{array}$} & \multicolumn{2}{|c|}{$\begin{array}{l}\text { Lysozyme positive } \\
\text { macrophagesi } \\
\text { monocytes }\end{array}$} & \multicolumn{2}{|c|}{ Mast cells } & \multirow{2}{*}{$\begin{array}{l}\text { Albumir } \\
\text { (mg/mi) }\end{array}$} \\
\hline & & $\begin{array}{c}N \\
\left(\times 10^{7} / 1\right)\end{array}$ & $\%$ & $\begin{array}{c}N \\
\left(\times 10^{7} / 1\right)\end{array}$ & $\%$ & $\begin{array}{c}N \\
\left(\times 10^{7} / 1\right)\end{array}$ & $\begin{array}{l}\% \text { of } \\
\text { macro- } \\
\text { phages }\end{array}$ & $\left(\times^{N} 0^{4}\right)$ & $\%$ & \\
\hline \multicolumn{11}{|l|}{ Before exposure $(\mathrm{N}=22)$} \\
\hline $\begin{array}{l}\text { Median } \\
\text { Interquartile range }\end{array}$ & $\begin{array}{c}7.4 \\
5.4-10.2\end{array}$ & $\begin{array}{c}0.5 \\
0.3-0.7\end{array}$ & $\stackrel{6}{5-9}$ & $\begin{array}{c}6.3 \\
4.9-7.9\end{array}$ & $\begin{array}{c}92 \\
89-93\end{array}$ & $\begin{array}{c}0.6 \\
0.3-1.6\end{array}$ & $\begin{array}{l}12.5 \\
5-18\end{array}$ & $\begin{array}{c}2.7 \\
0.6-6.3\end{array}$ & $\begin{array}{c}0.28 \\
0.28-1.39\end{array}$ & $\begin{array}{c}41 \\
29-46\end{array}$ \\
\hline \multicolumn{11}{|l|}{$24 \mathrm{~h}$ after exposure } \\
\hline \multicolumn{11}{|l|}{$10 \mathrm{mg} / \mathrm{m}^{3}(\mathrm{~N}=10)$} \\
\hline $\begin{array}{l}\text { Median } \\
\text { Interquartile range }\end{array}$ & $\begin{array}{c}6.0 \\
5.0-9.6\end{array}$ & $\begin{array}{c}0.5 \\
0.3-1.1\end{array}$ & $\stackrel{7}{6-9}$ & $\begin{array}{c}4.9 \\
4.4-8.7\end{array}$ & $\begin{array}{c}91 \\
88-91\end{array}$ & $\begin{array}{r}0.8^{* * *} \\
0.5-1.4\end{array}$ & $\begin{array}{l}14^{* * *} \\
10-17\end{array}$ & $\begin{array}{c}5.6 \\
3.0-15.7\end{array}$ & $\begin{array}{c}0.83 \\
0.56-1.94\end{array}$ & $21-33$ \\
\hline \multicolumn{11}{|l|}{$13 \mathrm{mg} / \mathrm{m}^{3}(\mathrm{~N}=8)$} \\
\hline $\begin{array}{l}\text { Median } \\
\text { Interquartile range }\end{array}$ & $\begin{array}{c}9.1 \\
7.6-10.3\end{array}$ & $\begin{array}{c}0.8 \\
0.5-1.3\end{array}$ & $\begin{array}{l}13 \\
6-15\end{array}$ & $\begin{array}{c}7.8 \\
6.1-9.1\end{array}$ & $\begin{array}{c}85 \\
83-94\end{array}$ & $1.2^{1.4^{*}}$ & $\begin{array}{c}19^{*} \\
16-24\end{array}$ & $\begin{array}{c}9.9^{*} \\
5.9-14.4\end{array}$ & $\begin{array}{c}1.11 * * \\
0.56-1.94\end{array}$ & $42-58$ \\
\hline \multicolumn{11}{|l|}{$20 \mathrm{mg} / \mathrm{m}^{3}(\mathrm{~N}=8)$} \\
\hline $\begin{array}{l}\text { Median } \\
\text { Interquartile range }\end{array}$ & $\begin{array}{c}14.5^{* *} \\
8.0-19.8\end{array}$ & $\begin{array}{r}1.4^{* *} \\
0.5-4.0\end{array}$ & $83^{*}$ & $\begin{array}{c}12.4^{* *} \\
6.8-14.7\end{array}$ & $\begin{array}{l}82^{*} \\
76-90\end{array}$ & $\begin{array}{r}1.6^{\star *} \\
0.9^{*}-2.6\end{array}$ & $\frac{17^{*}}{15-18}$ & $\begin{array}{c}10.8 \\
7.8-24.1\end{array}$ & $\begin{array}{c}0.83 \\
0.56-2.22\end{array}$ & $34-53$ \\
\hline \multicolumn{11}{|l|}{$30 \mathrm{mg} / \mathrm{m}^{3}(\mathrm{~N}=8)$} \\
\hline $\begin{array}{l}\text { Median } \\
\text { Interquartile range }\end{array}$ & $\begin{array}{c}11.2^{*} \\
9.5-16.3\end{array}$ & $\begin{array}{c}1.2^{*} \\
0.8-1.6\end{array}$ & $8^{14^{*}}$ & $\begin{array}{c}10.4^{*} \\
8.4-13.0\end{array}$ & $\begin{array}{c}85^{*} \\
81-97\end{array}$ & $\begin{array}{c}1.7^{*} \\
1.3-2.4\end{array}$ & $15-25$ & $\begin{array}{c}17.3^{\star \star} \\
9.2-30.6\end{array}$ & $\begin{array}{c}1.67^{\star \star} \\
1.11-2.64\end{array}$ & $\begin{array}{c}39 \\
30-51\end{array}$ \\
\hline
\end{tabular}

ly). The increase was the most pronounced in the population of macrophages/monocytes that was stained positive for lysozyme.

The total and relative numbers of mast cells were significantly increased $24 \mathrm{~h}$ after exposure to $13 \mathrm{mg} / \mathrm{m}^{3}$ (5 ppm). Twenty-four hours after exposure to 20 $\mathrm{mg} / \mathrm{m}^{3}$ there were indications of an increase in the total number of mast cells $(P=0.058)$. The increase in mast cells reached a peak value after exposure to 30 $\mathrm{mg} / \mathrm{m}^{3}$, the median value of the total mast cell numbers being more than five times higher than before the exposure.

The relative and total amount of lymphocytes was significantly increased $24 \mathrm{~h}$ after exposure to 20 and $30 \mathrm{mg} / \mathrm{m}^{3}$ ( 8 and $11 \mathrm{ppm}$, respectively). The lymphocytosis was moderate with median values of 13 and $14 \%$ after the respective concentrations compared with a median of $6 \%$ before exposure. The median value of the total number of lymphocytes was more than doubled after exposure to 13,20 , and $30 \mathrm{mg} / \mathrm{m}^{3}$ (5, 8, and $11 \mathrm{ppm}$, respectively). The median $\mathrm{T}$ helper/cytotoxic-suppressor cell ratio and albumin concentrations in BAL fluid were not significantly changed after any exposure to $\mathrm{SO}_{2}$ concentration.

\section{Spirometry}

The lung function recordings with the Vitalograph ${ }^{(\mathrm{B})}$ immediately after the exposure and before the BAL showed small but nonsignificant decreases in the forced expiratory volume in $1 \mathrm{~s}\left(\mathrm{FEV}_{1.0}\right),<5 \%$ of the preexposure values.

\section{Symptoms}

Very mild symptoms from the eyes, nose, and throat were reported during the exposures without any sig- nificant difference between the exposure concentrations.

\section{Discussion}

The cytologic examination of the recovered bronchoalveolar lavage fluid showed that $\mathrm{SO}_{2}$ exposure gives an inflammatory cell reaction involving mast cells and alveolar macrophages even at the relatively low $\mathrm{SO}_{2}$ concentrations of $10-13 \mathrm{mg} / \mathrm{m}^{3}(4-5 \mathrm{ppm})$. The macrophage reaction was more pronounced in terms of increased lysozyme production in the cells, visible by specific staining, than the increase in the total number of macrophages. An increased number of lysozyme positive macrophages is considered a marker for macrophage activation $(18,19)$. It should be noted that an inflammatory cell reaction occurred at levels of $\mathrm{SO}_{2}$ that were previously regarded as safe and were below the short-term exposure limit for Sweden and several other countries, $13 \mathrm{mg} / \mathrm{m}^{3}(5 \mathrm{ppm})(5,20)$. The exposure limits are mainly based on studies with indirect methods to evaluate noxious lung effects, methods that are far less sensitive than those employed in this investigation. The cellular reactions that were found after the $\mathrm{SO}_{2}$ exposure may seem moderately pronounced when determined as the percentage of the total cell number and as the total cell numbers. It should be noted that these clearly defined reactive changes occurred after one single exposure of healthy nonsmoking subjects, while workers in some industries may be repeatedly exposed to similar doses in their indoor work environment $(2,4,5)$. The demonstrated inflammatory response was not associated with any symptoms or clinical airway obstruction that could 
serve as a warning signal of a noxious response in the lung to the inhaled $\mathrm{SO}_{2}$.

The inflammatory cellular reaction increased as the dose increased from 10 to $13 \mathrm{mg} / \mathrm{m}^{3}$ (4 to $5 \mathrm{ppm}$ ), and also to $20 \mathrm{mg} \mathrm{SO} \mathrm{SO}^{3}(8 \mathrm{ppm})$, when a significant lymphocytosis accompanied a further enhanced macrophage and mast cell response. There was, however, no significantly further increased cell reaction in the recovered BAL fluid at $30 \mathrm{mg} / \mathrm{m}^{3}(11 \mathrm{ppm})$, apart from an increase in the number of mast cells. These results could indicate that the dose-response curve for macrophage and lymphocyte response to $\mathrm{SO}_{2}$ exposure is not linear but has a declining slope above $20 \mathrm{mg}$ $\mathrm{SO}_{2} / \mathrm{m}^{3}(8 \mathrm{ppm})$. We believe that concentrations above $30 \mathrm{mg} / \mathrm{m}^{3}$ (11 ppm) must be examined before any definite conclusions can be drawn about the doseresponse relationship. In a recent study, a very pronounced increase of neutrophils was found in the BAL fluid of mongrel dogs $2 \mathrm{~h}$ after exposure through tracheostomy with an $\mathrm{SO}_{2}$ concentration of $52 \mathrm{mg} / \mathrm{m}^{3}$ (20 ppm) (21). After exposure to 133 and $520 \mathrm{mg} / \mathrm{m}^{3}$ (50 and $200 \mathrm{ppm}$ ) the neutrophils were accompanied by extremely high numbers of epithelial cells. These results contrast to ours and reflect a severe toxic damage to the airway and alveolar epithelium by high exposure concentrations. The absence of lymphocytes and mast cells in BAL fluid in the mentioned report (21) is still somewhat surprising and highlights the difficulties in extrapolating results from animal experiments to man.

We have recently demonstrated that alveolar macrophages, mast cells, and lymphocytes are involved in the early response to $\mathrm{SO}_{2}$ exposure (13). The exact mechanisms of the inflammatory response to $\mathrm{SO}_{2}$ in the human lung has, however, not been clarified. It may be that one or several of these cell types are involved in the primary mechanism by which $\mathrm{SO}_{2}$ triggers the inflammatry cell response. It could also be that $\mathrm{SO}_{2}$ alters the adherence of these cells to the airway epithelium or mucous layer and that this phenomenon makes them more easily lavaged. There are many other possible mechanisms behind the reactions, and the vast epithelial surfaces exposed to $\mathrm{SO}_{2}$ have immunologic capabilities that have, so far, not been extensively studied.

According to current concepts, the highly watersoluble gas $\mathrm{SO}_{2}$ is mainly absorbed in the nasopharynx during nasal breathing $(22,23)$ and most of the $\mathrm{SO}_{2}$ that enters the lung is believed to be absorbed in the trachea and proximal bronchi. The prominent erythema that was seen in these areas in our study during bronchoscopy indicate that a mucosal effect of $\mathrm{SO}_{2}$ had indeed occurred in these areas. It should be emphasized that it cannot be concluded from which airway levels (from the alveoli to the tip of the wedged fiberoptic bronchoscope) the different cell populations in the BAL fluid have been collected after the $\mathrm{SO}_{2}$ exposure. If the direct effects of $\mathrm{SO}_{2}$ on the lung mainly occur in the proximal regions, it would be logical to believe that the majority of the cells in the recovered lavage fluid is lavaged from the bronchi and bronchioli rather than from the alveolar region. We did not find any indication of increased alveolar permeability after exposure by measuring albumin in the BAL fluid. We believe that the pulmonary response to $\mathrm{SO}_{2}$ is more pronounced in terms of acute bronchitis/bronchiolitis than alveolitis.

We conclude that the inflammatory cell response that was found in the BAL fluid after $\mathrm{SO}_{2}$ exposure increased as the dose increased from 10 to $20 \mathrm{mg} / \mathrm{m}^{3}$, but that no further amplification of the reaction could be detected after $30 \mathrm{mg} / \mathrm{m}^{3}$. An inflammatory cell response in the BAL fluid was observed at and below the short-term exposure limit of Sweden and several other countries, $13 \mathrm{mg} / \mathrm{m}^{3}$. Well-defined cell reactions were found after one single exposure to $\mathrm{SO}_{2}$ concentrations that occur in peak exposures in occupational indoor environments worldwide. We find it possible that repeated exposures to these $\mathrm{SO}_{2}$ levels may cause persisting inflammation in the lungs of workers and that this phenomenon may be an important factor behind the increased incidence and morbidity of chronic lung diseases in workers exposed to $\mathrm{SO}_{2}$. The safety of the short-term exposure limit for $\mathrm{SO}_{2}$ is thus questioned.

\section{Acknowledgments}

This study was supported by grants from The National Association Against Heart and Chest Diseases, The Norrlands Gas AB Fund, and The Joint Committee for the North Health Region.

\section{References}

1. Huhti E, Ryhänen P, Vuopala U, Torkkanen J. Chronic respiratory disease among pulp mill workers in an Arctic area in Northern Finland. Acta Med Scand 1970; 187:433-40.

2. Kolmodin-Hedman B, Swensson A. Nordiska expertgruppen för gränsvärdes-dokumentation. Svaveldioxid [Nordic expert group for documentation of occupational exposure limits. Sulfur dioxide]. Stockholm: Arbetarskyddsverket, 1984. (Arbete och hälsa 1984;18:1-63).

3. Logan WPD. Mortality of the London fog incident. Lancet 1953;1:336-8.

4. Stjernberg N, Eklund A, Nyström L, Rosenhall L, Emmelin A, Strömqvist L.-H. Prevalence of bronchial asthma and chronic bronchitis in a community in Northern Sweden; relation to environmental and occupational exposure to sulphur dioxide. Eur J Respir Dis 1985; $67: 41-9$.

5. World Health Organization. Sulphur oxides and suspended particulate matter. Geneva: World Health Organization, 1979. (Environmental health criteria 8.)

6. Poukkula A, Huhti E, Mäkaräinen M. Chronic respiratory disease among workers in a pulp mill: a ten-year follow-up. Chest 1982;81:285-9.

7. Stjernberg N, Nyström L, Lindén G, Rosenhall L, Mikaelsson B. Chronic bronchitis in sulphate pulp factory workers - a cross-sectional study. $\mathrm{Br} \mathrm{J}$ Ind Med (in press).

8. Fine JM, Gordon T, Sheppard D. The roles of $\mathrm{pH}$ and 
ionic species in sulfur dioxide- and sulfite-induced bronchoconstriction. Am Rev Respir Dis 1987;136:1122-6.

9. Koenig JQ, Piersson WE, Horike M, Frank R. Effects of inhaled sulfur dioxide $\left(\mathrm{SO}_{2}\right)$ on pulmonary function in healthy adolescents: exposure to $\mathrm{SO}_{2}$ alone or $\mathrm{SO}_{2}+$ sodium chloride droplet aerosol during rest and exercise. Arch Environ Health 1982;37:5-9.

10. Rom WN, Wood SD, White GL, Moon Bang K, Reading JC. Longitudinal evaluation of pulmonary function in copper smelter workers exposed to sulfur dioxide. Am Rev Resp Dis 1986;133:830-3.

11. Utell MJ, Morrow PE, Hyde RW. Airway reactivity to sulfate and sulfuric acid aerosols in normal and asthmatic subjects. J Air Pollut Control Assoc 1984;34: $931-5$.

12. Witec TJ, Schachter EN. Airway responses to sulfur dioxide and metacholine in asthmatics. J Occup Med 1985;27:265-8.

13. Sandström T, Stjernberg N, Andersson M-C, KolmodinHedman B, Lundgren R, Angström T. Is the short-term limit value for sulphur dioxide exposure safe? - effects of controlled chamber exposure investigated with broncho alveolar lavage. $\mathrm{Br} \mathbf{J}$ Ind Med (in press).

14. Sandström T, Kolmodin-Hedman B, Stjernberg N, Andersson $\mathrm{M}-\mathrm{C}$, Löfvenius $\mathrm{G}$. Challenge test for sulfur dioxide - symptom and lung function measurements. Scand J Work Environ Health 1988;14(suppl 1):77-9.

15. Cedergren A, Wikby A, Bergner K. Comparison of high precision coulometric and West-Gaeke methods with the gravimetric method for preparation of standard sulfur dioxide gas blends using permeation tubes. Anal Chem 1975;47:100-6.

16. Strobel S, Milter HRP, Ferguson A. Human intestinal mucosal mast cells: evaluation of fixation and staining techniques. J Clin Pathol 1981;34:851-8.

17. Laurell C-B. Electroimmuno assay. Scand J Clin Lab Invest 1972;124(suppl 29):21-37.

18. Cohn ZA, Wiener $\mathrm{E}$. The particualte hydrolases of macrophages: I. comparative enzymology, isolation and properties. J Exp Med 1963;118:991-1008.

19. Leakes ES, Myrvik QN. Changes in the morphology and lysozyme content of free alveolar cells after intravenous injection of killed BCG in oil. J Reticuloendothel Soc 1968;5:33-53.

20. National Institute of Occupational Health. The National Institute of Occupational Health statutes: exposure limits. Stockholm: Liber tryck, 1981. (AFS 1981:1.)

21. Kariya ST, Shore SA, Andersson K, Skornik WA, Drazen JM. Lung inflammation and airway responsiveness: effects of acute sulfur dioxide $\left(\mathrm{SO}_{2}\right)$ gas exposure. Am Rev Respir Dis 1988;137:377.

22. Brain J. The uptake of inhaled gases by the nose. Ann Otol Rhinol Laryngol 1970;79:529-40.

23. Frank NR, Yoder RE, Brain JD, Yokoyama E. $\mathrm{SO}_{2}$ ( ${ }^{35} \mathrm{~S}$ labeled) absorption by the nose and mouth under conditions of varying concentration and flow. Arch Environ Health 1969;18:315-22.

Received for publication: 22 September 1988 